\title{
KARAKTERISASI MERISTIK DAN MORFOMETRIK TIGA GENERASI IKAN TENGADAK Barbonymus schwanenfeldii ASAL KALIMANTAN BARAT, INDONESIA
}

\author{
Deni Radona, Irin Iriana Kusmini, dan Muhammad Hunaina Fariduddin Ath-thar \\ Balai Riset Perikanan Budidaya Air Tawar dan Penyuluhan Perikanan \\ (Naskah diterima: 19 Januari 2017; Revisi final: 2 Maret 2017; Disetujui publikasi: 20 Maret 2017)
}

\begin{abstract}
ABSTRAK
Dalam mendukung program domestikasi ikan tengadak asal Kalimantan Barat perlu dilakukan karakterisasi fenotipe untuk mengevaluasi perubahan tingkat keragaman dari tiga generasi ikan tengadak dan antisipasi keberhasilan domestikasi yang dilakukan. Analisis keragaman fenotipe dilakukan secara biometri berdasarkan meristik dan morfometrik terhadap 30 ekor sampel dari masing-masing generasi. Hasil karakterisasi menunjukkan pada tiga generasi ikan tengadak terdapat kesamaan ciri-ciri meristik. Hasil truss morfometrik berdasarkan analisis fungsi kanonikal terhadap 21 karakter, generasi yang berbeda tersebar pada kuadran yang berbeda, G-0 berada di bagian bawah diagram kanonikal (kuadran 3 dan 4), G-1 berada di bagian kiri diagram (kuadran 1 dan 4), sedangkan G-2 sebagian besar di bagian atas diagram (kuadran 1, 2, dan 3). Berdasarkan truss morfometrik, kesamaan karakter terdapat pada garis yang menghubungkan ujung mulut dan ujung operculum bawah (A-1), garis yang menghubungkan awal sirip dorsal dan awal sirip anal (B6), garis yang menghubungkan awal sirip dorsal dan akhir sirip anal (C3), garis yang menghubungkan awal sirip anal dan akhir sirip anal (C5), garis yang menghubungkan akhir sirip dorsal dan akhir sirip anal (C6), garis yang menghubungkan akhir sirip dorsal dan awal sirip ekor atas (D1), garis yang menghubungkan akhir sirip dorsal dan akhir sirip ekor bawah (D3), dan garis yang menghubungkan akhir sirip anal dan awal sirip ekor bawah (D5). Analisis indeks keseragaman intrapopulasi (sharing component) menunjukkan keseragaman genetik tertinggi terdapat pada ikan tengadak generasi pertama (G-1) dan kedua (G-2) sebesar 76,7\% dan indeks keseragaman interpopulasi sebesar 3,3\%30\%antara populasi ikan tengadak G-0 dan G-2. Ketersediaan jumlah induk yang dipijahkan dapat memengaruhi indeks keseragaman populasi.
\end{abstract}

\section{KATA KUNCl: ikan tengadak; fenotipe; meristik; morfometrik}

ABSTRACT: Meristic and morphometric characterization of three generations of tinfoil barb from West Kalimantan, Indonesian. By: Deni Radona, Irin Iriana Kusmini, and Muhammad Hunaina Fariduddin Ath-thar

To support the domestication programs of tinfoil barb from West Kalimantan, it is important to undertake phenotypic charaterization in order to evaluate the changes in diversity of three generations of tinfoil barb and to anticipate the successfull domestication programs performed. Phenotype diversity was analyzed biometrically based on meristic and morphometric on 30 samples from each generation. The results showed that the three generations of tinfoil barbs have similar characteristic of meristic. Theresults of the canonical function of truss morphometric analysis on 21 characteristics showed the measurement distribution of three generation are in different quadrants. G-0 were located at the bottom of the diagram canonical (quadrant 3 and 4), G-1 was in the left side of the diagram (quadran 1 and 4), while G-2 mostly at the top of the diagram (quadran 1,2, and 3). Based on truss morphometric, the similarity characters were in the line connecting the end of mouth and the lower end of operculum (A1), the line connecting the beginning of dorsal fin and beginning of anal fin (B6), the line connecting the beginning of dorsal fin and end of anal fin (C3), the line connecting the beginning of anal fin and end of anal fin (C5), the line connecting the end of dorsal fin and end of anal fin (C6), the line connecting the end of dorsal fin and beginning of upper part of caudal fin (D1), the line connecting

\# Korespondensi: Balai Riset Perikanan Budidaya Air Tawar dan

Penyuluhan Perikanan. Jl. Sempur No. 1, Bogor 16154,

Indonesia. Tel. + (0251) 8313200

E-mail: deniradona_kkp@yahoo.com 
the end of dorsal fin and beginning of lower part of caudal fin (D3), and the line connecting the end of anal fin and beginning of lower part of caudal fin (D5). The analysis of intrapopulation similarity index showed the highest index of genetic similarity was in G-1 and G-2 (76.7\%) while, interpopulation similarity index of $3.3 \% 30.0 \%$ was found G0 and G-2 of tinfoil barb. The availability of broodstock can influence population similarity index.

\section{KEYWORDS: tinfoil barb; phenotypic; meristic; morphometric}

\section{PENDAHULUAN}

Ikan tengadak Barbonymus schwanenfeldii merupakan ikan asli perairan tawar Indonesia yang tersebar di Pulau Sumatera, Jawa, dan Kalimantan. Di Kalimantan Barat, ikan tengadak bernilai ekonomis tinggi sebagai ikan konsumsi. Ikan tengadak digemari masyarakat karena cita rasanya. Selain itu, ikan tengadak berpotensi sebagai ikan hias karena bentuknya unik dengan tubuh berwarna perak kekuningan dan sirip ekor berwarna merah jingga (Gustiano et al., 2015).

Pelestarian ikan tengadak di perairan umum diharapkan dapat mencegah terjadi kepunahan. Pelestarian ikan tengadak bisa dimulai dari proses domestikasi. Upaya domestikasi sangat diharapkan dapat menjaga kelestarian sumber daya dan meningkatkan produktivitas melalui pengolahan secara berkelanjutan. Menurut Sukadi et al. (2009), pengembangan akuakultur berbasis ikan jenis lokal harus dilakukan dalam upaya mempertahankan keanekaragaman hayati (biodiversity) dan mengembangkan budidaya untuk ketahanan pangan. Sebagai upaya mendukung proses domestikasi perlu dilakukan karakterisasi sumber daya genetik. Karakterisasi sumber daya genetik dapat dilakukan melalui pengamatan fenotipe. Fenotipe ikan dapat menjelaskan status suatu populasi berdasarkan kemiripan atau perbedaan bentuk badan (Sneath, 1995).

Karakteristik fenotipe bisa dilakukan secara meristik dan morfometrik. Meristik adalah ciri-ciri yang berkaitan dengan jumlah bagian tubuh dari ikan sedangkan morfometrik adalah ciri-ciri yang berkaitan dengan ukuran tubuh atau bagian tubuh ikan. Karakter fenotipe telah lama digunakan dalam biologi perikanan untuk mengukur kemiripan (Bagherian \& Rahmani, 2009; Gjedrem, 2005; Tave, 1993). Di Indonesia, karakterisasi fenotipe pada ikan-ikan lokal sudah dilakukan pada ikan tengadak asal Jawa dan Sumatera (Radona, 2016), ikan gurami Osphronemus gouramy (Radona et al., 2017), ikan sepat Trichogaster trichopterus (Iskandariah et al., 2015), ikan betok Anabas testudineus (Bungas, 2014), dan ikan gabus Channa striata (Gustiano et al., 2013). Karakter fenotipe dapat mencerminkan tingkat kebugaran populasi sehingga memudahkan untuk melakukan seleksi sumber daya genetik dalam proses budidaya selanjutnya.
Pada penelitian ini, karakterisasi fenotipe dilakukan untuk mendukung program domestikasi ikan tengadak asal Kalimantan Barat dalam melihat perubahan tingkat keragaman dari tiga generasi dan antisipasi keberhasilan domestikasi yang dilakukan. Tujuan dari penelitian ini adalah mengevaluasi keragaman fenotipe tiga generasi ikan tengadak G-0, G-1, dan G-2 hasil budidaya sebagai informasi dasar untuk menunjang keberhasilan budidaya ikan tengadak yang berkelanjutan.

\section{BAHAN DAN METODE}

Kegiatan dilakukan di Balai Budidaya Ikan Sentral, Anjungan Pontianak dan Instalasi Penelitian Plasma Nutfah Perikanan Air Tawar, Cijeruk-Bogor pada bulan Mei-November 2016.

\section{Sampel Ikan Uji}

Ikan tengadak yang diukur merupakan ikan koleksi yang berasal dari Balai Budidaya Ikan Sentral Anjungan, Pontianak, Unit Pelaksana Teknis dari Dinas Kelautan dan Perikanan Provinsi Kalimantan Barat. Pembentukan populasi setiap generasi melalui pemijahan secara massal dengan perbandingan 1:1 (satu ekor jantan membuahi satu ekor betina) dari induk generasi sebelumnya yang terseleksi berdasarkan pertumbuhan yang cepat. Ikan tengadak diintroduksi ke Instalasi Penelitian Plasma Nutfah Perikanan Air Tawar dengan menggunakan sistem transportasi tertutup selama 12 jam. Ikan tengadak diadaptasi terlebih dahulu dengan melakukan pemeliharaan pada kolam tanah berukuran $8 \mathrm{~m} \times 5 \mathrm{~m}$ selama 30 hari, setelah itu dilakukan pengukuran. Ikan tengadak pada setiap generasi dipilih berdasarkan kelengkapan tubuhnya. Karakterisasi fenotipe yang meliputi aspek meristik dan morfometrik dilakukan terhadap 30 ekor sampel ikan setiap generasi. Ikan tengadak generasi awal (G-0) berukuran panjang standar (PS) 21,43 $\pm 1,21 \mathrm{~cm}$ dan bobot tubuh (BT) 432,25 \pm 81,23 g, merupakan hasil tangkapan alam. Ikan tengadak generasi pertama (G-1) berukuran PS 18,90 $\pm 1,54 \mathrm{~cm}$ dan BT 265,94 \pm 57,49 g; merupakan hasil pemijahan secara massal dari induk G-0 sebanyak 25 ekor jantan dan 25 ekor betina, sedangkan ikan tengadak generasi kedua (G-2) berukuran PS $16,30 \pm 0,90 \mathrm{~cm}$ dan BT 156,00 $\pm 26,43 \mathrm{~g}$, merupakan hasil pemijahan secara massal dari induk G-1 sebanyak 30 ekor jantan dan 30 ekor betina. 


\section{Pengamatan Meristik}

Karakteristik meristik mengacu pada Saanin (1995), dilakukan dengan cara menghitung jumlah jarijari sirip dorsal, pectoral, ventral, caudal, dan anal, serta jumlah sisik sepanjang gurat sisi/linea lateralis (LL).

\section{Pengamatan Morfometrik}

Truss morfometrik diukur dengan metode pengukuran dan penentuan titik-titik truss berdasarkan Brzesky \& Doyle (1988). Pembuatan titik-titik truss dilakukan dengan cara meletakkan ikan di atas kertas yang telah dilapisi plastik bening dan styrofoam. Masing-masing titik ditandai dengan menggunakan jarum sesuai dengan pola truss morfometrik, meliputi: pengukuran jarak titik-titik tanda yang dibuat pada kerangka tubuh (Gambar 1 dan Tabel 1).

\section{Analisis Data}

Hasil pengukuran truss morfometrik seluruh karakter dikonversi ke dalam rasio dengan membagi nilai karakter terukur terhadap nilai panjang standar (PS). Analisis karakter meristik dilakukan secara kualitatif. Sebaran karakter truss morfometrik intra dan interpopulasi dilakukan dengan ANOVA menggunakan SPSS versi 18 dan ditampilkan dalam diagram fungsi kanonikal, serta analisis indeks keseragaman (sharing component).

\section{HASIL DAN BAHASAN}

\section{Karakteristik Meristik Ikan Tengadak Asal Kalimantan Barat}

Karakter meristik berkaitan dengan penghitungan jumlah pada bagian tubuh ikan. Nilai pengukuran meristik yang meliputi jumlah jari-jari sirip pada ikan tengadak tiga generasi (G-0, G-1, dan G-2) ditampilkan dalam Tabel 2.

Ciri-ciri meristik merupakan salah satu parameter dalam suatu spesies. Oleh karena itu, apabila penanganan suatu spesies dalam proses domestikasi dilakukan dengan benar, ciri-ciri meristik tidak akan mengalami perubahan secara signifikan di luar dari batas kisaran. Hasil perhitungan menunjukkan jumlah jari-jari sirip pada ketiga generasi ikan tengadak memiliki nilai yang sama, D. I.9, P. I.11-13, V. I.8, A. I. 6-8, C. 15-17, dan LL. 31-36. Nilai perhitungan jarijari sirip pada ikan tengadak ini sama dengan perhitungan yang dilakukan Gante et al. (2008). Jarijari sirip pada ikan tengadak menunjukkan jumlah dan kisaran karakter meristik ikan pada famili Cyprinidae umumnya (Cordova et al., 2016). Sebaliknya, penanganan domestikasi suatu populasi yang tidak tepat akan mengakibatkan adanya perubahan akibat terjadinya abnormalitas (Kirpichnikov, 1981). Berdasarkan hasil yang diperoleh dari perhitungan karakter meristik dapat dikemukakan bahwa domestikasi tiga generasi ikan tengadak yang dilakukan telah dapat berjalan dengan benar, dicirikan dengan tidak adanya perubahan karakter meristik dari setiap generasi.

\section{Karakteristik Morfometrik Ikan Tengadak Asal Kalimantan Barat}

Keragaman fenotipe terhadap 21 karakter pada tiga generasi (G-0, G-1, dan G-2) ikan tengadak dan nilai rata-rata truss morfometrik disajikan pada Tabel 3. Keragaman morfometrik dinyatakan dalam koefisien keragaman karakter (CV) dan nilai CV disajikan dalam

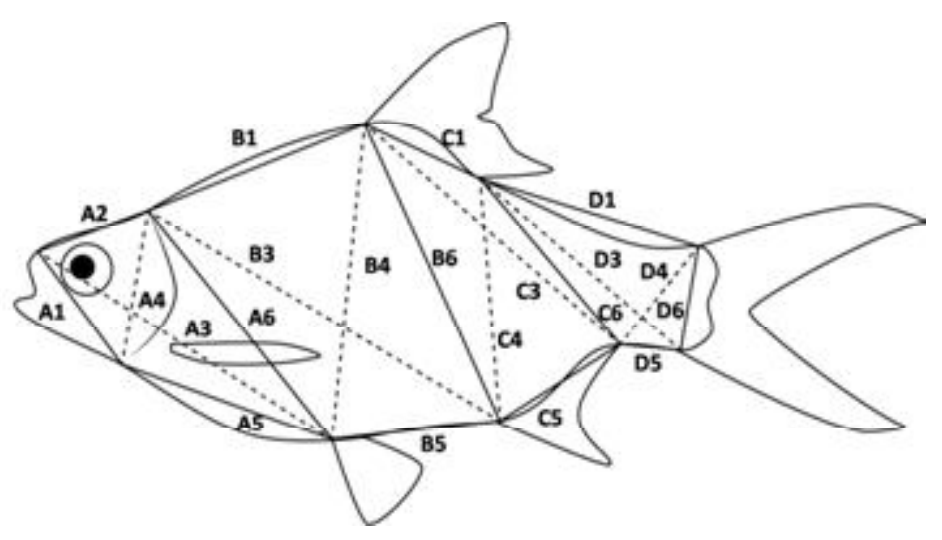

Gambar 1. Titik pengukuran truss morfometrik ikan tengadak asal Kalimantan Barat

Figure 1. Measurement point of truss morphometric tinfoil barb from West of Kalimantan 
Tabel 1. Deskripsi 21 karakter untuk truss morfometrik pada ikan tengadak asal Kalimantan Barat

Table 1. Description of 21 characters for truss morphometric of tinfoil barb from West of Kalimantan

\begin{tabular}{|c|c|c|}
\hline $\begin{array}{l}\text { Bidang truss } \\
\text { Truss area }\end{array}$ & $\begin{array}{l}\text { Kode } \\
\text { Code }\end{array}$ & Deskripsi jarak (Description of distance) \\
\hline \multirow{6}{*}{$\begin{array}{l}\text { Kepala } \\
\text { Head }\end{array}$} & A-1 & $\begin{array}{l}\text { Ujung mulut-ujung operculum bawah } \\
\text { End of mouth-the lower end of operculum }\end{array}$ \\
\hline & $A-2$ & $\begin{array}{l}\text { Ujung mulut-batas akhir tulang kepala } \\
\text { End of mouth-latter part of skull }\end{array}$ \\
\hline & A-3 & Ujung mulut-sirip ventral (end of mouth-ventral fin ) \\
\hline & A-4 & $\begin{array}{l}\text { Ujung operculum bawah-batas akhir tulang kepala } \\
\text { The lower end of operculum-latter part of skull }\end{array}$ \\
\hline & $A-5$ & $\begin{array}{l}\text { Ujung operculum bawah-sirip ventral } \\
\text { The lower end of operculum-ventral fin }\end{array}$ \\
\hline & A-6 & Batas akhir tulang kepala-sirip ventral (Latter part of skull-ventral fin ) \\
\hline \multirow{5}{*}{$\begin{array}{l}\text { Tengah tubuh } \\
\text { Middle body }\end{array}$} & B-1 & $\begin{array}{l}\text { Batas akhir tulang kepala-awal sirip dorsal } \\
\text { Latter part of skull-beginning of dorsal fin }\end{array}$ \\
\hline & B-3 & $\begin{array}{l}\text { Batas akhir tulang kepala-awal sirip anal } \\
\text { Latter part of skull-beginning of anal fin }\end{array}$ \\
\hline & B-4 & Sirip ventral-awal sirip dorsal (Ventral fin-beginning of dorsal fin ) \\
\hline & B-5 & Sirip ventral-awal sirip anal (Ventral fin-beginning of anal fin ) \\
\hline & B-6 & $\begin{array}{l}\text { Awal sirip dorsal-awal sirip anal } \\
\text { Beginning of dorsal fin-beginning of anal fin }\end{array}$ \\
\hline \multirow{5}{*}{$\begin{array}{l}\text { Tubuh belakang } \\
\text { Rear body }\end{array}$} & C-1 & Awal sirip dorsal-akhir sirip dorsal (Beginning of dorsal fin-end of dorsal fin ) \\
\hline & C-3 & Awal sirip dorsal-akhir sirip anal (Beginning of dorsal fin-end of anal fin ) \\
\hline & C-4 & Awal sirip anal-akhir sirip dorsal (Beginning of anal fin-end of dorsal fin ) \\
\hline & C-5 & Awal sirip anal-akhir sirip anal (Beginning of anal fin-end of anal fin ) \\
\hline & C-6 & Akhir sirip dorsal-akhir sirip anal (End of dorsal fin-end of anal fin ) \\
\hline \multirow{5}{*}{$\begin{array}{l}\text { Pangkal ekor } \\
\text { Caudal peduncle }\end{array}$} & D-1 & $\begin{array}{l}\text { Akhir sirip dorsal-awal sirip ekor atas } \\
\text { End of dorsal fin-beginning of upper part of caudal fin }\end{array}$ \\
\hline & D-3 & $\begin{array}{l}\text { Akhir sirip dorsal-awal sirip ekor bawah } \\
\text { End of dorsal fin-beginning of lower part of caudal fin }\end{array}$ \\
\hline & D-4 & $\begin{array}{l}\text { Akhir sirip anal-awal sirip ekor atas } \\
\text { End of anal fin-beginning of upper part of caudal fin }\end{array}$ \\
\hline & D-5 & $\begin{array}{l}\text { Akhir sirip anal-awal sirip ekor bawah } \\
\text { End of anal fin-beginning of lower part of caudal fin }\end{array}$ \\
\hline & D-6 & $\begin{array}{l}\text { Awal sirip ekor atas-akhir sirip ekor bawah } \\
\text { Beginning of upper part of caudal fin-beginning of lower part of caudal fin }\end{array}$ \\
\hline
\end{tabular}

Tabel 4. Hasil analisis Wilks lambda dan Lavene test (ANOVA) menunjukkan kesamaan pada delapan karakter terukur.

Keragaman morfometrik berdasarkan 21 karakter (Tabel 4) yang dianalisis dengan Wilks lambda dan Lavene test (ANOVA) menunjukkan kesamaan karakter $(P>0,05)$ pada bagian kepala, yaitu ujung mulut-ujung operculum bawah (A1), di bagian tengah tubuh yaitu, awal sirip dorsal-awal sirip anal (B6), di tubuh belakang, yaitu awal sirip dorsal-akhir sirip anal (C3), awal sirip anal-akhir sirip anal (C5), akhir sirip dorsal-akhir sirip anal (C6), dan bagian pangkal ekor, yaitu akhir sirip dorsal-awal sirip ekor atas (D1), akhir sirip dorsalawal sirip ekor bawah (D3), dan akhir sirip anal-awal sirip ekor bawah (D5). Nilai koefisien keragaman suatu karakter mengindikasikan tingkat variabilitas karakter 
Tabel 2. Karakterisasi meristik ikan tengadak asal Kalimantan Barat

Table 2. M eristic charaterization of tinfoil barb from West Kalimantan

\begin{tabular}{|c|c|c|c|c|c|}
\hline \multirow{3}{*}{$\begin{array}{c}\text { Karakter meristik } \\
\text { Meristic characterization }\end{array}$} & \multicolumn{5}{|c|}{ Ukuran rata-rata (Average size) } \\
\hline & \multicolumn{3}{|c|}{ Penelitian (Present study) } & \multicolumn{2}{|c|}{ Referensi (Reference) } \\
\hline & G-0 & G-1 & G-2 & Gante et al. (2008) & Bleeker (1853) \\
\hline Sirip dorsal (Dorsal fin ) & 1.9 & 1.9 & 1.9 & IV. 9 & IV. 8-9 \\
\hline Sirip pectoral (Pectoral fin) & I. $11-13$ & I. $11-12$ & I. $11-12$ & I. 14 & I. 14 \\
\hline Sirip ventral (Ventral fin ) & 1.8 & 1.8 & $1.7-8$ & 1.8 & 1.8 \\
\hline Sirip anal (Anal fin ) & 1.6 & 1.6 & 1. 6-8 & III. 6 & III. 5-6 \\
\hline Sirip caudal (Caudal fin ) & $15-17$ & $16-17$ & $16-17$ & $18-19$ & 19 \\
\hline Linear literalis (Linea lateralis) & $33-36$ & $31-35$ & $31-35$ & - & - \\
\hline
\end{tabular}

Keterangan (Notes): - = tidak ada data (No data)

Tabel 3. Nilai rata-rata karakter truss morfometrik tiga generasi ikan tengadak asal Kalimantan Barat

Table 3. Average value of truss morphometric characters of three generations of tinfoil barb from West Kalimantan

\begin{tabular}{ccccc}
\hline \multirow{2}{*}{$\begin{array}{c}\text { Ruang truss } \\
\text { Truss area }\end{array}$} & \multirow{2}{*}{$\begin{array}{c}\text { Karakter morfometrik } \\
\text { Morphom etric characters }\end{array}$} & \multicolumn{3}{c}{ Rataan (Average) } \\
\cline { 3 - 5 } & & G-0 & G-1 & G-2 \\
\hline \multirow{3}{*}{ Kepala } & A-1 & $0.188 \pm 0.025$ & $0.191 \pm 0.026$ & $0.186 \pm 0.011$ \\
Head & A-2 & $0.169 \pm 0.017$ & $0.183 \pm 0.014$ & $0.166 \pm 0.011$ \\
& A-3 & $0.549 \pm 0.052$ & $0.522 \pm 0.028$ & $0.531 \pm 0.018$ \\
& A-4 & $0.230 \pm 0.028$ & $0.239 \pm 0.022$ & $0.223 \pm 0.011$ \\
& A-5 & $0.375 \pm 0.034$ & $0.350 \pm 0.022$ & $0.370 \pm 0.018$ \\
& A-6 & $0.483 \pm 0.027$ & $0.463 \pm 0.025$ & $0.466 \pm 0.018$ \\
\hline \multirow{4}{*}{ Tengah tubuh } & B-1 & $0.383 \pm 0.032$ & $0.366 \pm 0.028$ & $0.361 \pm 0.017$ \\
Middle body & B-3 & $0.648 \pm 0.010$ & $0.622 \pm 0.019$ & $0.626 \pm 0.021$ \\
& B-4 & $0.492 \pm 0.018$ & $0.504 \pm 0.026$ & $0.472 \pm 0.022$ \\
& B-5 & $0.246 \pm 0.031$ & $0.254 \pm 0.025$ & $0.226 \pm 0.016$ \\
Tubuh belakang & B-6 & $0.501 \pm 0.049$ & $0.498 \pm 0.032$ & $0.498 \pm 0.018$ \\
Rear body & C-1 & $0.178 \pm 0.018$ & $0.178 \pm 0.013$ & $0.193 \pm 0.014$ \\
& C-3 & $0.476 \pm 0.045$ & $0.484 \pm 0.035$ & $0.485 \pm 0.017$ \\
& C-4 & $0.374 \pm 0.015$ & $0.380 \pm 0.026$ & $0.365 \pm 0.013$ \\
& C-5 & $0.145 \pm 0.013$ & $0.156 \pm 0.021$ & $0.154 \pm 0.010$ \\
& C-6 & $0.318 \pm 0.031$ & $0.321 \pm 0.036$ & $0.314 \pm 0.013$ \\
\hline \multirow{3}{*}{$\begin{array}{c}\text { Pangkal ekor } \\
\text { Caudal peduncle }\end{array}$} & D-1 & $0.311 \pm 0.028$ & $0.307 \pm 0.036$ & $0.302 \pm 0.019$ \\
& D-3 & $0.392 \pm 0.035$ & $0.382 \pm 0.039$ & $0.374 \pm 0.016$ \\
& D-4 & $0.229 \pm 0.021$ & $0.236 \pm 0.015$ & $0.220 \pm 0.013$ \\
& D-5 & $0.157 \pm 0.019$ & $0.144 \pm 0.019$ & $0.136 \pm 0.013$ \\
& D-6 & $0.150 \pm 0.018$ & $0.157 \pm 0.007$ & $0.148 \pm 0.009$ \\
\hline
\end{tabular}

yang bersangkutan pada suatu populasi. Tingkat variabilitas suatu karakter fenotipe mencerminkan variabilitas genotipe populasi (Falconer \& Mackay, 1993; Gjedrem, 2005). Koefisien keragaman populasi ikan tengadak G-0, G-1, dan G-2 berkisar antara 3,02\%
$12,98 \%$ Nilai CV yang rendah pada ikan tengadak asal Kalimantan Barat ini merupakan fenomena yang serupa pada kegiatan domestikasi ikan-ikan lokal lainnya seperti ikan tengadak asal Jawa dan Sumatera (Kusmini et al., 2016) dan ikan gurami (Radona et al., 2017). 
Tabel 4. Analisis Wilks lambda dan Lavene test (ANOVA) koefisien variasi pada 21 karakter morfometrik tiga generasi ikan tengadak asal Kalimantan Barat

Table 4. Wilks lambda analysis and Lavene test (ANOVA) coefficient of variation from 21 truss morphometric characters of three generations of tinfoil barb from West Kalimantan

\begin{tabular}{|c|c|c|c|c|c|}
\hline \multirow{2}{*}{$\begin{array}{c}\text { Karakter } \\
\text { morfometrik } \\
\text { Morphometric } \\
\text { characters }\end{array}$} & \multicolumn{3}{|c|}{$\begin{array}{l}\text { Koefisien keragaman } \\
\text { Coefficient of variation }(\%)\end{array}$} & \multirow{2}{*}{$\begin{array}{l}\text { Significant } \\
\text { Wilks lam bda }\end{array}$} & \multirow[t]{2}{*}{$\begin{array}{l}\text { Significant } \\
\text { ANOVA }\end{array}$} \\
\hline & G-0 & G-1 & G-2 & & \\
\hline$A-1$ & 13.57 & 13.44 & 5.81 & .736 & .487 \\
\hline$A-2$ & 10.53 & 7.64 & 6.54 & $.000 *$ & $.000 *$ \\
\hline$A-3$ & 9.64 & 5.27 & 3.40 & $.011^{*}$ & $.000 *$ \\
\hline$A-4$ & 12.61 & 9.26 & 5.10 & $.026 *$ & $.000 *$ \\
\hline$A-5$ & 9.36 & 6.19 & 4.90 & $.001 *$ & $.001 *$ \\
\hline A-6 & 10.0 & 5.46 & 3.79 & . 076 & $.000 *$ \\
\hline B-1 & 8.36 & 7.63 & 4.82 & $.016 *$ & $.002 *$ \\
\hline B-3 & 9.31 & 3.02 & 3.36 & $.035 *$ & $.000 *$ \\
\hline B-4 & 9.76 & 5.18 & 4.64 & $.004 *$ & $.000 *$ \\
\hline B-5 & 12.51 & 9.75 & 6.92 & $.000 *$ & .005 \\
\hline B-6 & 9.78 & 6.38 & 3.65 & .977 & .792 \\
\hline C-1 & 10.39 & 7.41 & 7.03 & $.000 *$ & $.001^{*}$ \\
\hline$C-3$ & 9.44 & 7.16 & 3.48 & .527 & .367 \\
\hline C-4 & 9.38 & 6.96 & 3.67 & .109 & $.000 *$ \\
\hline$C-5$ & 8.72 & 13.56 & 6.19 & $.005^{*}$ & .237 \\
\hline C-6 & 9.90 & 11.32 & 4.16 & .624 & .386 \\
\hline D-1 & 9.15 & 11.85 & 6.25 & .571 & .342 \\
\hline D-3 & 8.86 & 10.09 & 4.29 & .168 & .054 \\
\hline D-4 & 9.30 & 6.44 & 5.72 & $.004 *$ & $.005^{*}$ \\
\hline D-5 & 12.32 & 12.98 & 9.92 & $.000 *$ & .095 \\
\hline D-6 & 11.80 & 4.39 & 6.18 & $.017^{*}$ & $.000 *$ \\
\hline
\end{tabular}

Uji signifikan dilakukan untuk mengetahui karakter yang dapat digunakan sebagai penciri dari suatu jenis ikan. Hasil analisis fungsi kanonikal (Gambar 2) memperlihatkan bahwa karakter morfologi individu pada populasi ikan tengadak G-0 bersinggungan dengan ikan tengadak $\mathrm{G}-2$, tetapi tidak bersinggungan dengan ikan tengadak G-1. Hasil ilustrasi fungsi kanonikal memperlihatkan bahwa karakter morfologi individu setiap populasi terdistribusi pada kuadran yang berbeda. Ikan tengadak G-0 berada di kuadran 3 dan 4, G-1 berada di kuadran 1 dan 4 sedangkan G-2 berada pada kuadran 1, 2, dan 3.

Perbedaan karakter morfologi dari ketiga generasi ini mungkin terjadi karena faktor lingkungan. Menurut Soewardi (2007) dan Li et al. (1993), sebagian besar variasi fenotipe antar generasi dapat disebabkan oleh faktor lingkungan. Kondisi lingkungan perairan dari ketiga generasi ikan tengadak pada saat dilakukan pengukuran berbeda terutama pada parameter suhu, oksigen terlarut, dan nitrat. Pengukuran G-0 dan G-2 dilakukan di Balai Budidaya Ikan Sentral Anjungan dengan media pemeliharaan bersuhu $\left(29^{\circ} \mathrm{C}-33^{\circ} \mathrm{C}\right)$, oksigen terlarut (4,57-6,65 mg/L), dan amonia (0,151$0,212 \mathrm{mg} / \mathrm{L})$, sedangkan ikan tengadak G-1 dilakukan pengukuran di Instalasi Penelitian Plasma Nutfah Perikanan Air Tawar Bogor dengan media pemeliharaan bersuhu $\left(24^{\circ} \mathrm{C}-28^{\circ} \mathrm{C}\right)$, oksigen terlarut $(3,31-4,78$ $\mathrm{mg} / \mathrm{L})$, dan amonia (0,050-0,029 mg/L).

Berdasarkan analisis indeks keseragaman (sharing component) fenotipe intrapopulasi menunjukkan bahwa populasi ikan tengadak G-1 dan G-2 memiliki indeks keseragaman yang tinggi yaitu $76,7 \%$ dibandingkan dengan ikan tengadak G-0 sebesar 65,0\% (Tabel 5). Indeks keseragaman interpopulasi ditemukan rendah 3,3\%30\%antara populasi ikan tengadak G-0 dan G-2.

Keragaman fenotipe merupakan parameter kunci kebugaran populasi yang menjamin keberlanjutannya dan kemampuan merespons secara pasif seleksi alam ataupun buatan (Lorenzen et al., 2012). Ragam fenotipe dapat memberikan gambaran status 


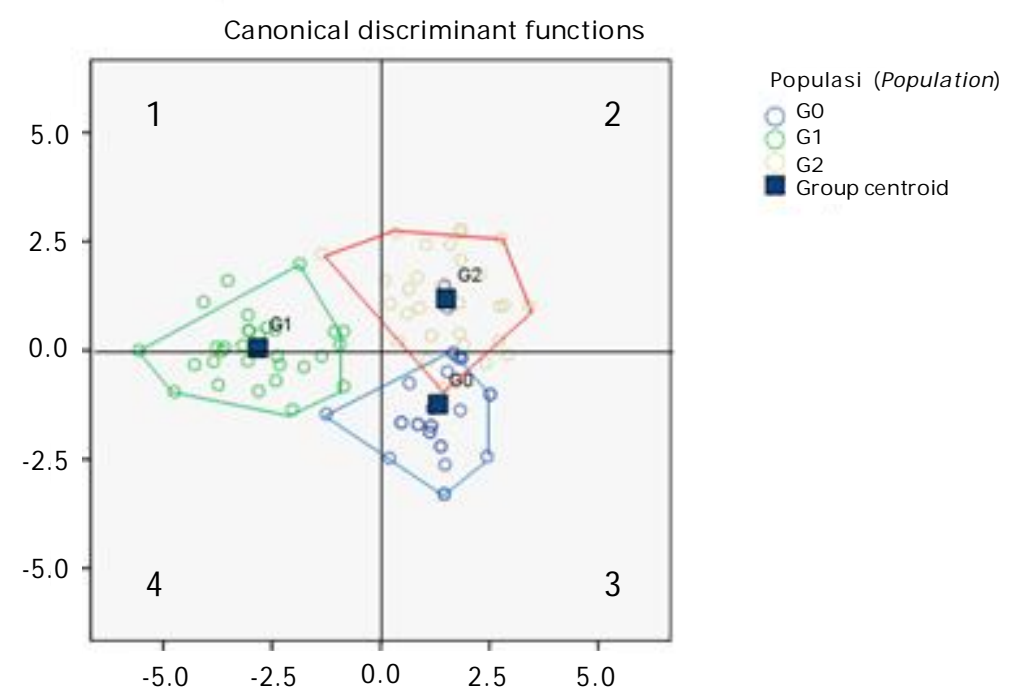

Gambar 2. Penyebaran karakter morfologi individu pada populasi tiga generasi ikan tengadak asal Kalimantan Barat

Figure 2. Individual morphological characters distribution in a population of three generations of tinfoil barb from West Kalimantan

Tabel 5. Nilai persentase sharing component tiga generasi ikan tengadak asal Kalimantan Barat

Table 5. The percentage value of sharing component of three generations of tinfoil barb from West Kalimantan

\begin{tabular}{ccccc}
\hline $\begin{array}{c}\text { Populasi } \\
\text { Population }\end{array}$ & G-0 & G-1 & G-2 & $\begin{array}{c}\text { Jumlah } \\
\text { Total }\end{array}$ \\
\hline G-0 & 65.0 & 5.0 & 30.0 & 100.0 \\
G-1 & 10.0 & 76.7 & 13.3 & 100.0 \\
G-2 & 20.0 & 3.3 & 76.7 & 100.0 \\
\hline
\end{tabular}

kebugaran dari populasi. Semakin tinggi ragam fenotipe maka kemampuan ikan beradaptasi pada lingkungan semakin tinggi sedangkan rendahnya ragam fenotipe dapat menurunkan kemampuan adaptasi dan produktivitas. Rendahnya ragam fenotipe bisa disebabkan oleh ketersediaan jumlah induk yang dipijahkan dalam proses budidaya sangat sedikit sehingga berpotensi meningkatnya kejadian silang dalam (inbreeding) atau perkawinan sekerabat (Gjedrem et al., 2012). Menurut Ujjania \& Kohli (2011), fenotipe ikan pada umumnya mengindikasikan potensi pertumbuhan yang beda. Terkait dengan usaha domestikasi, salah satu aspek yang perlu diperhatikan dan berperan penting dalam program domestikasi adalah penyediaan induk untuk budidaya, sehingga dapat meningkatkan produktivitas ikan tengadak.

\section{KESIMPULAN}

Karakter meristik pada ikan tengadak asal Kalimantan Barat tidak berbeda antar generasi. Pada karakter truss morfometrik tiga generasi ikan tengadak menunjukkan kesamaan karakter di bagian kepala, yaitu ujung mulut-ujung operculum bawah (A1), di bagian tengah tubuh yaitu, awal sirip dorsal-awal sirip anal (B6), di tubuh belakang, yaitu awal sirip dorsal-akhir sirip anal (C3), awal sirip anal-akhir sirip anal (C5), akhir sirip dorsal-akhir sirip anal (C6), dan bagian pangkal ekor, yaitu akhir sirip dorsal-awal sirip ekor atas (D1), akhir sirip dorsal-awal sirip ekor bawah (D3), dan akhir sirip anal-awal sirip ekor bawah (D5). Berdasarkan indeks keseragaman (sharing component) fenotipe intrapopulasi, ikan tengadak G-1 dan G-2 memiliki indeks keseragaman tertinggi $(76,7 \%$. 


\section{UCAPAN TERIMA KASIH}

Ucapan terima kasih disampaikan kepada Balai Penelitian dan Pengembangan Budidaya Air Tawar, Bogor karena sudah mendanai kegiatan ini melalui APBN 2016 dan Balai Budidaya Ikan Sentral Anjungan, Pontianak. Terima kasih juga kepada bapak Dr. Rudhy Gustiano atas saran dan masukannya dalam penulisan makalah ini, kepada Bapak Sudarmaji, dan Fera Permata Putri atas bantuan yang diberikan selama penelitian.

\section{DAFTAR ACUAN}

Bagherian, A., \& Rahmani, H. (2009). Morphological discrimination between two populations of shemaya Chalcalburnus chalciodes Actinopterygii, Cyprinidae using a truss network. Animal Biodiversity and Conservation, 32(1), 1-8.

Brzesky, V.J., \& Doyle, R.W. (1988). A morphometric criterion for sex discrimination in tilapia. In Pullin, R.S.V., Bhukaswan, T., Tonguthai, K., and Maclan, J.L. (Eds.). The second ISTA, Bangkok, Thailand. ICLARM conference Proceedings, 15, 439-444.

Bungas, K. (2014). Keragaman fenotipe ikan betok Anabas testudineus di perairan rawa gambut. Jurnal Ilmu Hewani Tropika, 3(1), 33-38.

Cordova, C.A., Campos, G.R., Findley, L.T., Chon, J.M., Millan, L.E., \& Romero, A.V. (2016). Morphometric and meristic characterization of the endemic Desert chub Gila eremica (Teleostei: Cyprinidae) and its related congeners in Sonora, Mexico. Revista Mexicana de Biodiversidad, 87, 390-398.

Falconer, F.S., \& Mackay, T.F.C. (1996). Introduction to quantitative genetics. Longman, England, 464 $\mathrm{pp}$.

Gante, H.F., Costa, L.M., Micael, J., \& Alves, M.J. (2008). First record of Barbonymus schwanenfeldii Bleeker in the Iberian Peninsula. Journal of fish Biology, 72(4), 1089-1094.

Gjedrem, T., Robinson, N., \& Rye, M. (2012). The importance of selective breeding in aquaculture to meet future demands for animal protein: a review. Aquaculture, 350-353, 117-129.

Gjedrem, T. (2005). Selection and breeding program in aquaculture. Akvaforsk, As.Norway, 364 pp.

Gustiano, R., Kusmini, I.I., \& Ath-thar, M.F.H. (2015). Mengenal sumber daya genetik ikan spesifik lokal air tawar indonesia untuk pengembangan budidaya. IPB Press. Bogor, $51 \mathrm{hlm}$.

Gustiano, R., Oktaviani, T., Soelistyowati, D.T., Kusmini, I.I., Wahyutomo, \& Huwoyon, G.H. (2013). Analisa ragam genotipe RAPD dan fenotipe truss morphometric pada tiga populasi ikan gabus Channa striata. Berita Biologi, 12(3), 325-333.
Iskandariah, Soelistyowati, D.T., Gustiano, R., Kusmini, I.I., \& Huwoyon, G.H. (2015). Ragam genetik tiga populasi sepat siam asal Kalimantan menggunakan analisis RAPD dan pengukuran morfometrik truss. Berita Biologi, 14(1), 57-68.

Kirpichnikov, V.S. (1981). Genetic bases of fish selection. Springer-verlag, German, 410 pp.

Kusmini, I.I., Gustiano, R., Radona, D., Prakoso, V.A., Putri, F.P., \& Prihadi, T.H. (2016). Karakterisasi fenotipe dan genotipe tiga populasi ikan tengadak Barbonymus schwanenfeldii. J. Ris. Akuakultur, 11(3), 207-216.

Li, S., Cai, W., \& Zhou, B. (1993). Variation in morphology and biochemical genetic markers among populations of blunt snout bream Megalobrama amblycephala. Aquaculture, 111, 117-127.

Lorenzen, K., Beveridge, M.C.M., Mangel, M. (2012). Cultured fish: integrative biology and management of domestication and interactions with fish. Biology Review, 87, 639-660.

Radona, D., Nafiqoh, N., \& Arifin, O.Z. (2017). Studi biometri berdasarkan meristik dan morfometrik ikan gurame galur bastar dan bluesafir. Berita Biologi, 2017 (accepted).

Radona, D. (2016). Karakterisasi genotipe, biometrik dan performa silang luar potensial ikan tengadak Barbonymus schwanenfeldii asal Sumatera, Jawa dan Kalimantan. Tesis. Institut Pertanian Bogor. Bogor, $51 \mathrm{hlm}$.

Saanin, H. (1995). Taksonomi dan kunci identifikasi ikan. Bina Cipta. Bogor, $508 \mathrm{hlm}$.

Sneath, P.H.A. (1995). Thirty years of numerical taxonomy. Systematic Biology, 44, 281-298.

Sukadi, M.F., Nugroho. E., Kristanto, A.H., Komarudin, O., Widiyati, A., Gustiano, R., \& Djajasewaka, H. (2009). Kandidat komoditas ikan lokal air tawar untuk pengembangan budidaya di Kalimantan Selatan. Dalam Analisis Kebijakan Pembangunan Perikanan Budidaya 2009. Badan Penelitian dan Pengembangan Kelautan dan Perikanan. Pusat Penelitian dan Pengembangan Perikanan Budidaya, hlm. 57-69.

Soewardi, K. (2007). Pengelolaan keragaman genetik sumberdaya perikanan dan kelautan. Departemen Manajemen Sumberdaya Perairan, Institut Pertanian Bogor. Bogor, $153 \mathrm{hlm}$.

Tave, D. (1993). Genetic for Fish hatchery managers. Kluwer Academic Publishers. Netherland, 415 pp.

Ujjania, N.C., \& Kohli, M.P.S. (2011). Landmark based morphometric analysis for selected species of Indian major carp Catla catla (Ham 1822). Agriculture and Veterinary Science, 1(1), 64-74. 